\title{
Oral and Maxillofacial Trauma and the Use of Telemedicine in the Grampian Region of Scotland: a Retrospective Study
}

\author{
Colin Hutchison ${ }^{1}$, Roderick Morrison ${ }^{2}$ \\ ${ }^{1}$ Emergency Department, Glasgow Royal Infirmary, Scotland. \\ ${ }^{2}$ Department of Oral and Maxillofacial Surgery, Aberdeen Royal Infirmary, Scotland.
}

\author{
Corresponding Author: \\ Colin Hutchison \\ Emergency Department, Glasgow Royal Infirmary \\ 84 Castle Street, Glasgow \\ Scotland \\ E-mail: colin.hutchison@,nhs.net
}

\begin{abstract}
Objectives: To evaluate the amount and nature of adult facial trauma in Aberdeen, Scotland's third largest city, that requires referral to Aberdeen Royal Infirmary oral and maxillofacial surgery department by the Emergency Department and Grampian's telemedicine service over a six month period.

Material and Methods: A retrospective audit using oral and maxillofacial surgery trauma clinic and theatre records to identify Emergency Department (ED) notes for those patients presenting with facial trauma. ED notes were examined to extract demographic data on each patient as well as information on the nature and outcomes of the facial trauma. This data was compared with previously published national and international statistics.

Results: 137 patients were identified with a mean age of 33.7 years with a standard deviation of 16.7. 83.2\% of facial trauma victims were male and $62 \%$ of facial injuries were caused by alleged assault. Only 1 patient was referred to Aberdeen Royal Infirmary by telemedicine.

Conclusions: Aberdeen has a high number of injuries caused by interpersonal violence. Telemedicine is an underused resource in the referral and review of facial trauma at Aberdeen Royal Infirmary.
\end{abstract}

Keywords: telemedicine; maxillofacial injuries; emergency care.

Accepted for publication: 26 September 2012.

To cite this article:

Hutchison C, Morrison R. Oral and Maxillofacial Trauma and the Use of Telemedicine in the Grampian Region of Scotland: a Retrospective Study.

J Oral Maxillofac Res 2012;3(3):e2

URL: http://www.ejomr.org/JOMR/archives/2012/3/e2/v3n3e2ht.pdf

doi: $10.5037 /$ jomr.2012.3302 


\section{INTRODUCTION}

Facial trauma is very common in Scotland. Between 2001 and 2006 there were 82,461 patients with a facial injury diagnosis at the time of discharge from Scottish hospitals [1]. In 1997, a UK wide study found that facial injury accounted for at least $4 \%$ of all Accident and Emergency attendances. A figure believed to be a gross underestimation [2].

Facial injury can range from minor contusions and lacerations to complex hard and soft tissue injury requiring referral to one of the 156 oral and maxillofacial surgery (OMFS) units in the UK. Common hard tissue injuries requiring referral include fractures of the mandible, the zygoma, orbit and nasal bones, some of which will be treated conservatively with others requiring open reduction and internal fixation. Complex lacerations and fractures of the mandible requiring surgical treatment will tend to be admitted to the oral and maxillofacial department and operated on as soon as possible. Other bony facial injuries will be reviewed on an out-patient basis before a decision on definitive treatment is made [ $\underline{3}$.

Aberdeen Royal Infirmary (ARI) is the largest hospital within the National Health Service (NHS) of the Grampian region of Scotland. It is a teaching hospital and has around 900 beds [4]. It serves Aberdeen, the third largest city in Scotland, and the surrounding area. In 2008, it was estimated that there were over 450,000 people living in Aberdeen and Aberdeenshire [ $\underline{5}$ ]. Aberdeenshire extends to 6313 square kilometres, $8 \%$ of Scotland's overall territory [6].

ARI has a mid-sized oral and maxillofacial (OMFS) unit consisting of 4 consultants, 3 staff grades, 1 specialist trainee, 2 Foundation year 2 junior doctors (FY2) and 3 dental senior house officers (SHO). All referred facial injuries that do not require emergency hospital admission and surgical intervention are reviewed at the weekly trauma clinic by a consultant.

ARI has a large emergency department (ED), consisting of 10 consultants, 7 registrars, 6 General Practitioner Trainees (GPVT) and 6 Foundation Year junior doctors seeing over 90,000 new patients and 60,000 reviews per year. As well as the many attendees in person, the emergency department also runs Grampian Minor Injuries Telemedicine Service. The service has been operating since 2001 supporting 15 Minor Injury Units (MIUs) in community hospitals in the Grampian and Highland region. Over 120 new patients are seen by the telemedicine service each month [7]. Videoconferencing equipment allows the ARI ED clinician, aided by an on-site nurse, to take a history, examine and view radiographs from patients in these remote locations.
This allows for specialized consultation without the need for travel, thus improving patient quality of care and life. Only $3-9 \%$ of patients managed with telemedicine each year require transfer to the ED. Telemedicine at ARI is run primarily by the ED department but it does have the potential to play an important role in oral and maxillofacial surgery. Telemedicine in oral and maxillofacial surgery has been used in other centres to aid diagnosis and triage [8], assist out-patient referral [9] and even to augment surgical procedures with specialized input from another hospital [10].

The aims of this study were to evaluate the numbers and demographics of adult facial injuries referred to oral and maxillofacial surgery by the emergency department at Aberdeen Royal Infirmary and to investigate the use of telemedicine in the management of facial injury to determine if this valuable resource is utilised appropriately in oral and maxillofacial trauma at Aberdeen Royal Infirmary.

\section{MATERIAL AND METHODS}

Out-Patients referred to the OMFS department for investigation of facial injury are reviewed at the weekly trauma clinic. A 'trauma book' is kept containing a record of all patients seen as well as a brief note of the follow-up plans. The clinic reception diary contains details of those patients who were given trauma clinic appointments but failed to attend. Details of patients from both sources were collected spanning a seven month period between $1^{\text {st }}$ June 2010 and $31^{\text {st }}$ December 2010.

This method only identified patients who were deemed suitable for review on clinic. To determine patients that were admitted for operative management rather than first seen on clinic, theatre records were searched to gather data on patients operated on by the OMFS team, with facial trauma, between $1^{\text {st }}$ June and $31^{\text {st }}$ December 2010.

Emergency department record cards are kept for all patients seen in ARI ED. Using the names and patient unique Community Health Index (CHI) numbers gathered from operating theatre books and trauma clinic, ED notes were searched to find those patients who had been seen by the ED staff prior to oral and maxillofacial surgery referral between $1^{\text {st }}$ June 2010 and $30^{\text {th }}$ November 2010. Data from December 2010 was used to identify patients seen in the ED in late November but not operated on or reviewed in clinic until December. Patients attending the ED in December were not included in the study. Having identified the individual record cards, each was anonymised before data was collected on patient demographics as well as 
method of injury and presentation to the department. Names and CHI numbers were used only to identify the records but were not used in the data collection or analysis. The study design was presented to Aberdeen Medical School Elective Submissions Panel and approved on ethical grounds prior to data collection.

\section{RESULTS}

Trauma clinic and theatre records identified 376 patients. Of these 139 had attended the ARI adult ED during the six month period and had ED notes available. Two patients were under the age of 16 and so excluded from the study leaving a data set of 137 adults aged 16 or older referred to the OMFS unit by the ED between the $1^{\text {st }}$ of June and the $30^{\text {th }}$ of November 2010 . The mean age was 33.7 years (range $16-89$ ) with a standard deviation (SD) of 16.7. A total of $114(83.2 \%)$ patients were male and $23(16.8 \%)$ were female. The majority of patients were between the ages of 16 and 34 (Figure 1). Patients with facial injury attended most often on Saturday or Sunday (43.8\%) and attendance were spread throughout the day (Figures 2 and 3).

By far the most common mechanism of injury was alleged assault (62\%) with falls (17.4\%) the second most frequent cause (Table 1).

Of the 85 alleged assaults, the method of assault was primarily by punches to the face $(56.5 \%)$ with the remainder involving kicks (14.1\%) and weapons $(12.9 \%)$. Weapons used included crowbars, ashtrays, bottles and hammers. In $14.1 \%$ of cases, no method was recorded in the notes (Table 2).

\section{Telemedicine}

Postcode of attendees and distance of travel

There are 15 MIU's connected to ARI by telemedicine. The most distant is Forres (Table 3), it would require a round trip of over 150 miles to attend ARI ED

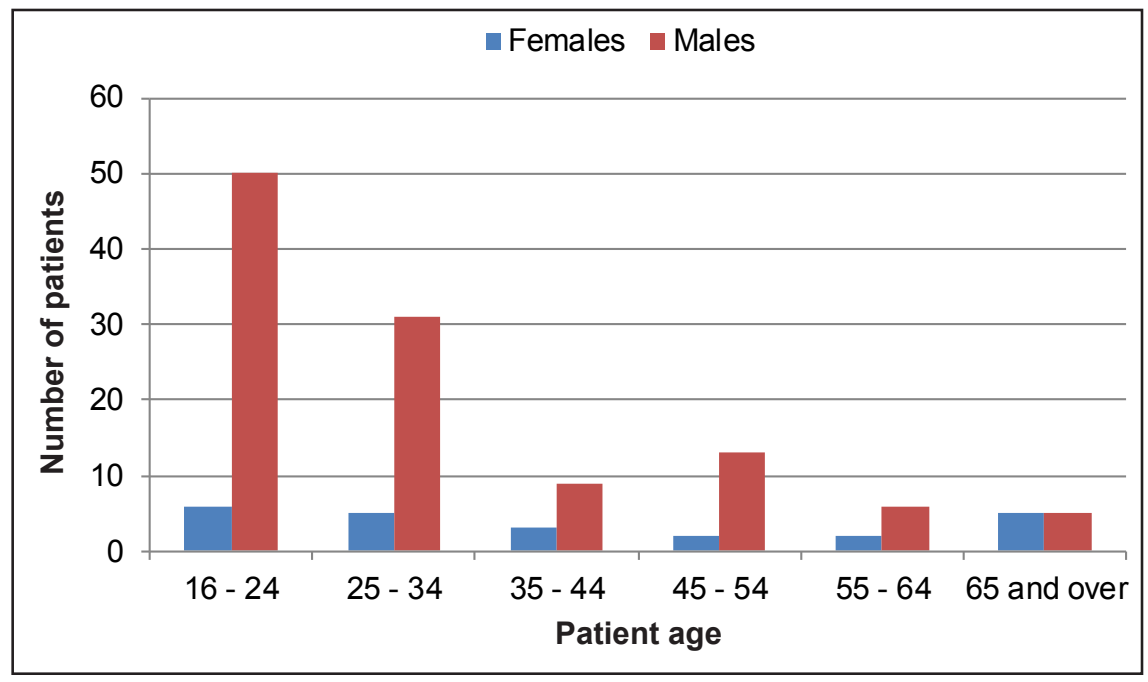

Figure 1. Distribution of patients by age and gender.

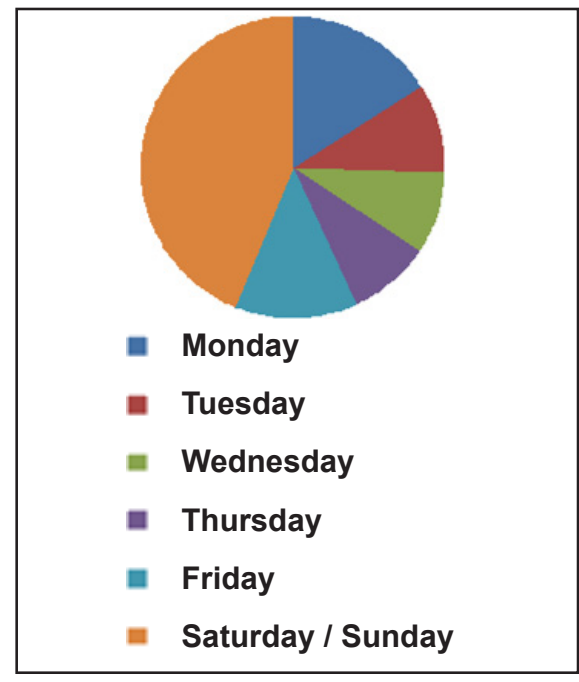

Figure 2. Day of presentation.

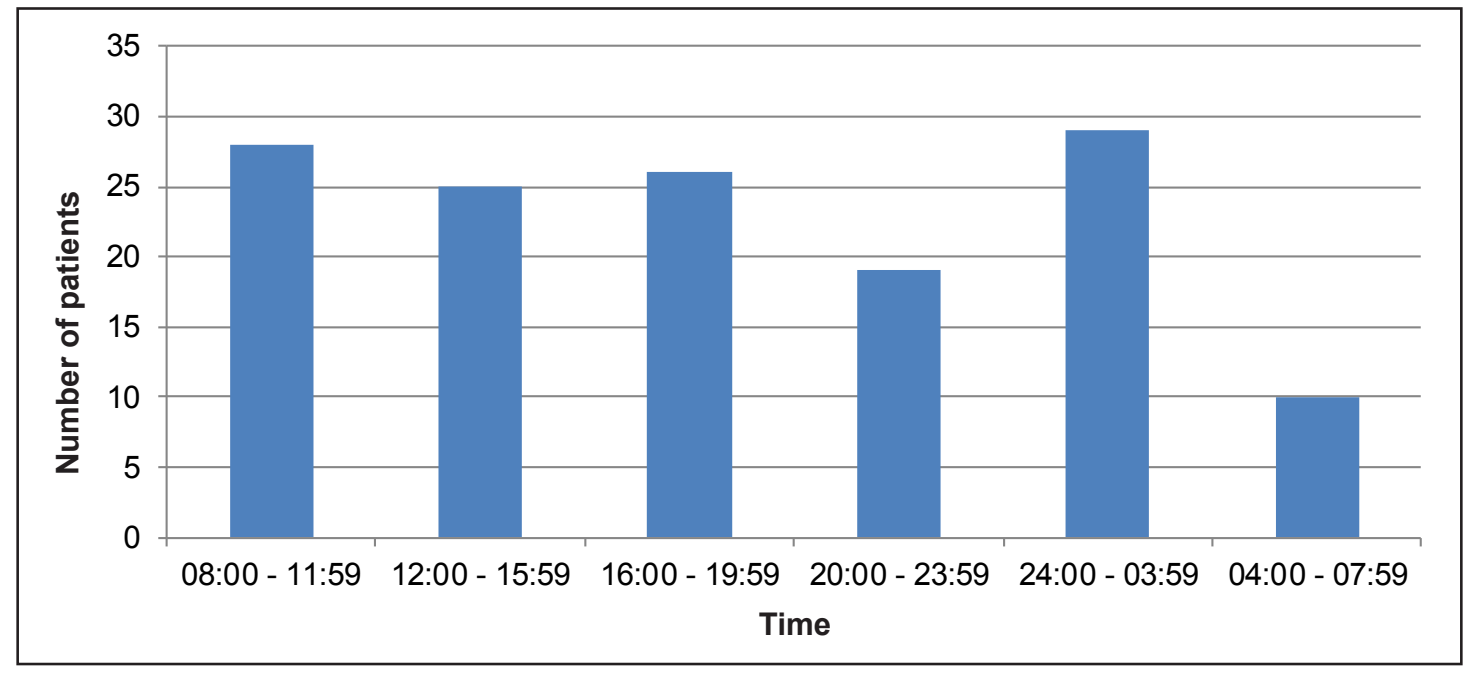

Figure 3. Time of presentation. 
Table 1. Aetiology of patient's injury

\begin{tabular}{lc}
\hline Aetiology of injury & $\begin{array}{c}\text { Number of patients and percentage } \\
\text { of sample }\end{array}$ \\
\hline Alleged assault & $85(62.0 \%)$ \\
Fall & $24(17.6 \%)$ \\
Sport related & $8(5.8 \%)$ \\
Work related & $2(1.5 \%)$ \\
Other & $9(6.6 \%)$ \\
Unknown & $9(6.6 \%)$ \\
\hline
\end{tabular}

Table 2. Nature of alleged assault

\begin{tabular}{lc}
\hline Nature of assault & $\begin{array}{c}\text { Number of patients and percentage of } \\
\text { sample }\end{array}$ \\
\hline Punch & $48(56.5 \%)$ \\
Kick & $12(14.1 \%)$ \\
Weapon & $11(12.9 \%)$ \\
Other & $2(2.4 \%)$ \\
Unknown & $12(14.1 \%)$ \\
\hline
\end{tabular}

in person from Forres. Using postcode data, it was possible to work out the area that each patient lived in and therefore the distance between the patient's home and ARI (Figure 4). By far the most common region of attendees with facial trauma was Aberdeen City $(63.5 \%)$. Despite $19 \%$ living within an area served by a MIU (and many others living closer to an MIU than ARI) with access to telemedicine, only 1 patient $(0.7 \%)$ was referred via the service.

\section{Telemedicine Referral}

The only case referred to ARI by telemedicine was a female patient brought to Peterhead MIU, 32.3 miles from ARI (Table 3 ) by police following facial trauma secondary to alleged domestic abuse. The nurse led team at MIU contacted ARI ED and the patient was reviewed by senior ED staff using telemedicine. The purpose of the consultation was to determine whether urgent transfer and admission to ARI were necessary. This was not thought to be necessary at the time. The patient attended the oral and maxillofacial trauma clinic some 3 days later. She was diagnosed with a nasal bone fracture and underwent manipulation under anaesthetic.

\section{Trauma Clinic Outcome}

Of the 137 ED cards, and therefore confirmed trauma patients, 117 had been referred to the trauma clinic $(85.4 \%)$. The remaining $20(14.6 \%)$ had been admitted directly to the maxillofacial ward and theatre.
Table 3. Distance of Minor Injury Units (MIU) to Aberdeen Royal Infirmary (ARI) and availability of telemedicine and X-ray facilities

\begin{tabular}{lccc}
\hline MIU & $\begin{array}{c}\text { Telemedicine } \\
\text { available? }\end{array}$ & $\begin{array}{c}\text { X-rays } \\
\text { available? }\end{array}$ & $\begin{array}{c}\text { Distance from ARI } \\
\text { (miles) }\end{array}$ \\
\hline Forres & Yes & No & 76.6 \\
Elgin & Yes & Yes & 64.9 \\
Buckie & Yes & Yes & 60.6 \\
Aberlour & Yes & No & 57 \\
Dufftown & Yes & No & 51.6 \\
Keith & Yes & Yes & 48.1 \\
Banff & Yes & Yes & 45.1 \\
Fraserburgh & Yes & Yes & 41.2 \\
Huntly & Yes & Yes & 37.7 \\
Peterhead & Yes & Yes & 32.3 \\
Aboyne & Yes & No & 30.8 \\
Turriff & Yes & Yes & 29.4 \\
Insch & Yes & No & 28 \\
Inverurie & Yes & No & 16.3 \\
Stonehaven & Yes & Yes & 15.5 \\
\hline
\end{tabular}

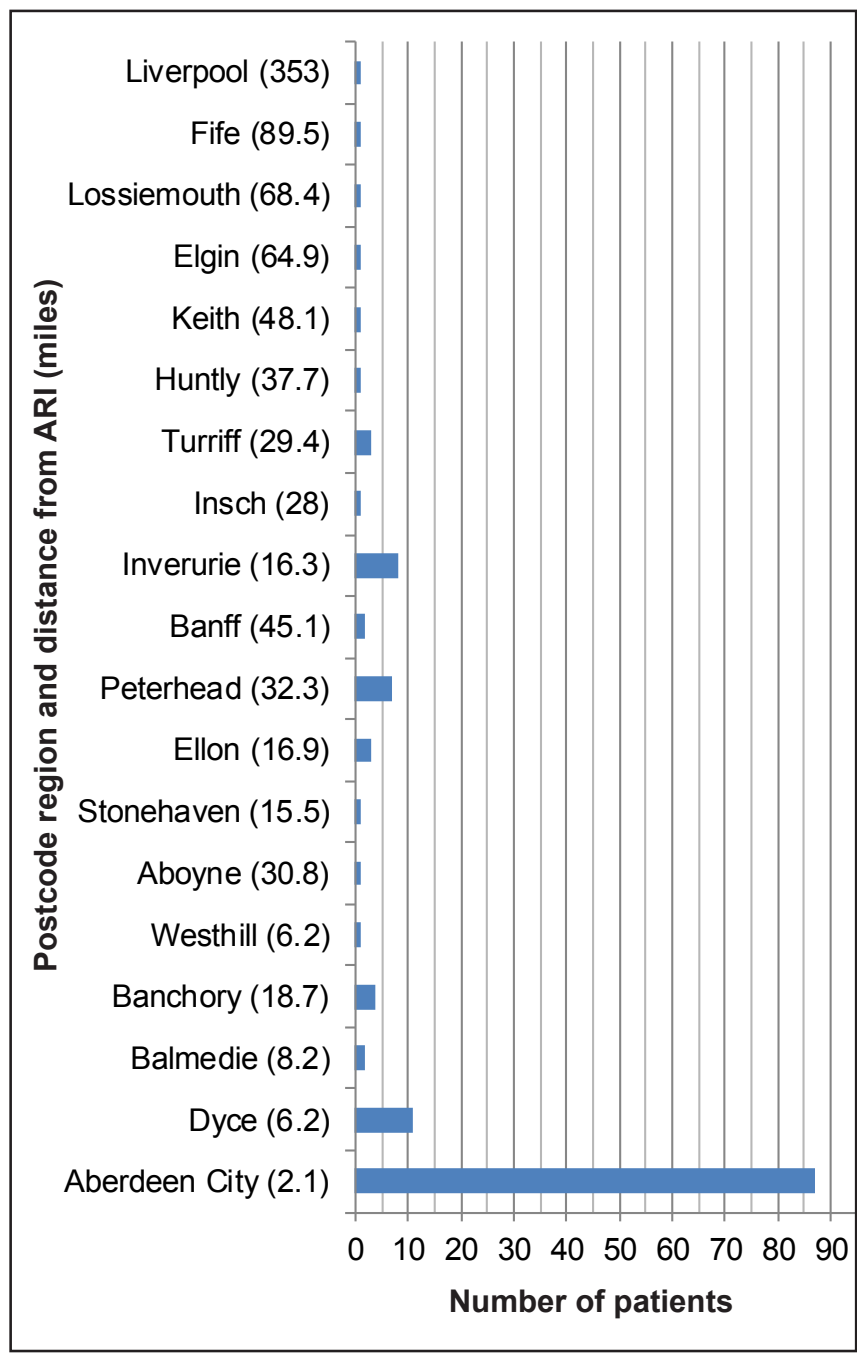

Figure 4. Postcode area and distance from ARI of attendees. 
The outcomes of the referral to the outpatient clinic are shown in Table 4. Those that were admitted following clinic review were operated upon. Most (33.3\%) trauma clinic reviews were discharged after one appointment. $22.2 \%$ failed to attend the arranged trauma clinic appointment.

\section{DISCUSSION}

The age of patients in this study (mean 33.7 years) is somewhat older than the 25.3 years found in the 1997 British Association of Oral and Maxillofacial Surgeons (BAOMS) UK wide survey of facial injuries [2]. This is unsurprising as BOAMS included all patients, regardless of age, rather than just adults. Patients under the age of 15 accounted for $39 \%$ of that data. However, similar characteristics were found in relation to young adults making up the majority of adult trauma [2]. A more recent UK facial injury survey from 2008 found a mean age of 29 years, closer to the Aberdeen value, despite including those under the age of 15 [11]. International data from Tokyo Medical and Dental University found over $50 \%$ of patients with maxillofacial fractures between 1977 and 1989 were between the ages of 10 and 29 [12]. Brazilian data from 1999 - 2004 showed the mean age of patients with maxillofacial fractures as 28 years [13].

In Aberdeen, as is seen in many other studies, males dominate facial injury referrals $[2,12-14]$. A male to female ratio of almost 5:1 was found. This is higher than the UK wide BOAMS study which found a ratio of only 2:1, increasing to $4: 1$ in assault cases [2].

One of the most striking and concerning features of the study was the high percentage of facial trauma secondary to alleged assault attending ARI. Inter-personal violence accounted for $67 \%$ of referrals to oral and maxillofacial surgery from the emergency department. This is much greater than in the previous UK studies which found assault the aetiological factor for only 24\% in 1997 [2] and $31 \%$ in 2008 [11]. Although these studies both included young children, who are less likely to suffer assaults, this is not enough to explain the large increase in Aberdeen. Data for 15 - 25 year olds in BOAMS UK wide 1997 study found $46 \%$ of facial injury was caused by assault, still markedly lower than in this study. International studies found a wider variation in assault data. Inter-personal violence is the cause of only $15.5 \%$ of maxillofacial fractures in Tokyo [12], 22.6\% of facial fractures in Brazil [13] but $75 \%$ of facial trauma presentations to a New Jersey ED [14]. Future studies could be aimed at finding an explanation for the large amount of trauma due to violence. Many studies have found an association between alcohol and drug use
Table 4. Trauma clinic review outcome

\begin{tabular}{lc}
\hline Trauma clinic review outcome & $\begin{array}{c}\text { Number of patients and } \\
\text { percentage of sample }\end{array}$ \\
\hline To be admitted & $24(20.5 \%)$ \\
Further clinic review & $23(19.7 \%)$ \\
Discharged & $39(33.3 \%)$ \\
Failed to attend & $26(22.2 \%)$ \\
Other & $2(1.7 \%)$ \\
Unknown & $3(2.6 \%)$ \\
\hline
\end{tabular}

and inter-personal violence $[\underline{1}, \underline{2}, \underline{15}, \underline{16}]$ and others have investigated the recurrent nature of facial injury due to assaults [14]. These areas were beyond the scope of this study but future studies could be designed to include this data. This may become increasingly important as violence reduction and alcohol awareness programmes are investigated and implemented as preventative measures $[\underline{15}, \underline{16}]$.

The majority of victims of domestic violence present with maxillofacial injuries [17] and it is important that dental and maxillofacial teams are aware of this and are equipped with the appropriate training and knowledge to identify domestic violence and provide information about where the individual can go for advice [18-20]. In facial injury not due to inter-personal violence, the most common cause was falls, followed by sport related injuries (Table 1). The number caused by road traffic accidents (RTA) was negligible. This is in contrast to older studies where RTAs were a major factor in facial injuries [21]. The introduction of seat-belt and drinkdriving legislation, as well as the widespread use of airbags is thought to have contributed to this decrease $[2,21]$.

The majority of patients resided in or near Aberdeen City $(63.5 \%)$. This was expected as the city is the main population base in the area with over 200,000 people residing there [5]. However the remainder lived outside the city in a more remote location. 19\% resided in an area with a MIU which had access to the telemedicine service and many others lived closer to a MIU than ARI ED. Despite this, almost all of these patients attended ARI in person and only 1 patient was referred using the telemedicine service. Given the wide geographical nature of the Aberdeenshire, and the increasingly common utilisation of the service for other injuries, this is a disappointing figure. Telemedicine can improve quality of care and should be used more frequently. Traditionally, specialist advice between centres is offered based on a telephone consultation, the clinical decision is therefore heavily influenced by the experience, clinical knowledge and communication skills of both the referrer and the receiving specialist. This can lead to incorrect diagnosis and inappropriate 
triaging of patients. Including images in the consultation, by using telemedicine, gives the minor injury unit access to specialized consultation of a higher standard than telephone alone improving diagnostic accuracy and improving patient triaging $[\underline{8}, \underline{22}, \underline{23}]$. Use of telemedicine could also decrease expensive and unnecessary transfers of oral and maxillofacial surgery patients from rural areas, not only improving patient quality of life but also optimising use of medical resources [24]. This was true in the case referred by telemedicine in our study, where urgent transfer was avoided for a patient who was more suitable for review on an out-patient clinic. Out-patient referrals may also be managed this way; Rollert et al. [25] showed that telemedicine consultation could be used effectively for pre-operative assessment in dentoalveolar surgery and Blomstrand et al. [9] highlighted the use of telemedicine images in effective out-patient diagnosis, avoiding the need for travel to attend an oral medicine specialist. In our study a third of trauma clinic referrals were discharged after only one appointment and a further $22.2 \%$ failed to attend appointments. Many of these patients could have been managed by telemedicine rather than travelling from a rural location to Aberdeen for an out-patient appointment. Fractured mandibles and lacerations require prompt review and treatment and so may be unsuitable for initial review by telemedicine. However, other injuries, such as suspected fractured zygoma, may be more appropriate as it is often helpful to allow a period for the swelling to resolve so that a more accurate assessment can be made. Delays of 5 to
7 days are not at all unreasonable, allowing time for a telemedicine appointment to be arranged [3] . For those patients that do require treatment, telemedicine has been shown to improve surgery by increasing expert involvement in care at an early stage [10].

\section{CONCLUSIONS}

This study has shown that a large amount of the facial trauma referred to the oral and maxillofacial team in Aberdeen Royal Infirmary is due to interpersonal violence. Reasons behind this and possible preventative measures should be investigated and instituted with the aim of reducing this. Telemedicine has the potential to be an important part of trauma review in oral and maxillofacial units providing service to rural areas although it is currently underutilised by National Health Service Grampian. Appropriate use of telemedicine can improve patient care and use of medical resources.

\section{ACKNOWLEDGEMENTS AND DISCLOSURE}

The authors report no conflicts of interest related to the study. The authors would like to thank Dr. Fiona Mair (Aberdeen Royal Infirmary, Emergency Department) for her help in study design and data collection and Dr. Tatiana MacFarlane (University of Aberdeen) for her help in editing the manuscript.

\section{REFERENCES}

1. Conway DI, McMahon AD, Graham L, Snedker S, McCluskey K,Devlin M, Goodall C. The scar on the face of Scotland: Deprivation and alcohol-related facial injuries in Scotland. J Trauma 2010 Mar;68(3):644-9. [Medline: 19918199] [doi: 10.1097/TA.0b013e3181a5ed18]

2. Hutchison IL, Magennis P, Shepherd JP, Brown AE. The BOAMS United Kingdom survey of facial injuries part 1: Aetiology and the association with alcohol consumption. Brit J Oral Max Surg 1998 Feb;36(1):3-13. [Medline: 9578248] [doi: 10.1016/S0266-4356(98)90739-2]

3. Hollier LH, Sharabi SE, Koshy JC, Stal S. Facial Trauma: General principles of management. J Craniofac Surg 2010 Jul;21(4):1051-3. [Medline: 20613558] [doi: 10.1097/SCS.0b013e3181e5701c]

4. NHS Grampian website. URL: www.nhsgrampian.org

5. Aberdeen City Council. Research and Information. 2008-based population projections Aberdeen City and Shire. Briefing Paper 2010/04.

6. Aberdeenshire profile. Aberdeenshire Council. URL: http://www.aberdeenshire.gov.uk/statistics/

7. Mair F, Ferguson J. More patients with minor injuries could be seen by telemedicine. J Telemed Telecare 2008;14(3):132-4. [Medline: 18430279] [doi: 10.1258/jtt.2008.003009]

8. Aziz SR, Ziccardi VB. Telemedicine using smartphones for oral and maxillofacial surgery consultation, communication, and treatment planning. J Oral Maxillofac Surg. 2009 Nov;67(11):2505-9. [Medline: 19837324] [doi: 10.1016/j.joms.2009.03.015]

9. Blomstrand L, Sand LP, Gullbrandsson L, Eklund B, Kildal M, Hirsch JM. Telemedicine-a complement to traditional referrals in oral medicine. Telemed J E Health. 2012 Sep;18(7):549-53. Epub 2012 Jul 23. [Medline: 22823077] [doi: 10.1089/tmj.2011.0207]

10. Ewers R, Schicho K, Wagner A, Undt G, Seemann R, Figl M, Truppe M. Seven years of clinical experience with teleconsultation in craniomaxillofacial surgery. J Oral Maxillofac Surg. 2005 Oct;63(10):1447-54. [Medline: 16182912] [doi: 10.1016/j.joms.2005.06.020] 
11. Muna J, Magennis P, Ridout F, Hutchison W, Marcenes W. The second UK National Facial Injury Survey: the demography, aetiology, nature of injury and treatment. (Abstract) Brit J Oral Max Surg 2009; 47: e58. [doi: 10.1016/j.bjoms.2009.06.093]

12. Tanaka N, Tomitsuka K, Shionoya K, Andou H, Kimijima Y, Tashiro T, Amagasa T. Aetiology of maxillofacial fracture. Br J Oral Maxillofac Surg.1994 Feb;32(1):19-23. [Medline: 8136332] [doi: 10.1016/0266-4356(94)90166-X]

13. Brasileiro BF, Passeri LA. Epidemiological analysis of maxillofacialfractures in Brazil: A 5-year prospective study. Oral Surg Oral Med Oral Pathol Oral Radiol Endod. 2006 Jul;102(1):28-34. [Medline: 16831669] [doi: 10.1016/j.tripleo.2005.07.023]

14. Laski R, Ziccardi VB, Broder HL, Janal M. Facial Trauma: A recurrentdisease? The potential role of disease prevention. J Oral Maxillofac Surg 2004 Jun;62(6):685-8. [Medline: 15170278] [doi: 10.1016/j.joms.2003.12.008]

15. Goodall CA, Ayoub AF, Crawford A, Smith I, Bowman A, Koppel D, Gilchrist G. Nurse-delivered brief interventions for hazardous drinkers with alcohol-related facial trauma: A prospective randomised controlled trial. Br J Oral Maxillofac Surg. 2008 Mar;46(2):96-101. [Medline: 18160192] [doi: 10.1016/j.bjoms.2007.11.014]

16. MacDonald S, Wells S, Giesbrecht $\mathrm{N}$, Cherpitel CJ. Demographic and substance use factors related to violent and accidental injuries: results from an emergency room study. Drug Alcohol Depen 1999;55: 53-61. [doi: 10.1016/S0376-8716(98)00184-7]

17. Le BT, Dierks EJ, Ueeck BA, Homer LD, Potter BF. Maxillofacial Injuries associated with domestic violence. J Oral Maxillofac Surg. 2001 Nov;59(11):1277-83. [Medline: 11688025] [doi: 10.1053/joms.2001.27490]

18. Coulthard P, Warburton AL. The role of the dental team in respondingto domestic violence. Br Dent J. 2007 Dec 8;203(11):645-8. [Medline: 18065984] [doi: 10.1038/bdj.2007.1066]

19. Warburton AL, Hanif B, Rowsell C, Coulthard P. Changes in the levelsof knowledge and attitudes of dental hospital staff about domestic violence following attendance at an awareness raising seminar. Br Dent J. 2006 Nov 25;201(10):653-9. [Medline: 17128240] [doi: 10.1038/sj.bdj.4814232]

20. Coulthard P, Warburton AL. Dentistry and domestic violence. Br Dent J. 2006 Nov 25;201(10):611. [Medline: 17128212] [doi: $10.1038 /$ sj.bdj.4814269]

21. Telfer MR, Jones GM, Sheperd JP. Trends in the aetiology of maxillofacial fractures in the United Kingdom (1977-1987). Br J Oral Maxillofac Surg. 1991 Aug;29(4):250-5. [Medline: 1911673] [doi: 10.1016/0266-4356(91)90192-8]

22. Hsieh CH, Tsai HH, Yin JW, Chen CY, Yang J, Jeng SF. Telecommunication with the mobile camera phone in digital soft-tissue injury: A feasibility study. Plast Recon Surg. 2004 Dec 114(7):1776-82. [Medline: 15577348] [doi: 10.1097/01.PRS.0000142402.07896.21]

23. Lowry J. The development of a telemedicine system for a centralized maxillofacial unit serving four towns. J Telemed Telecare 2001;7(Suppl. 1):58-9. [Medline: 11576494] [doi: 10.1258/1357633011936741]

24. Roccia F, Spada MC, Milani B, Berrone S. Telemedicine in Maxillofacial Trauma: A 2-Year Clinical Experience. J Oral Maxillofac Surg. 2005 Aug;63(8):1101-5. [Medline: 16094576] [doi: 10.1016/j.joms.2005.04.020]

25. Rollert MK, Strauss RA, Abubaker AO, Hampton C. Telemedicine consultations in oral and maxillofacial surgery. J Oral Maxillofac Surg. 1999 Feb;57(2):136-8. [Medline: 9973120] [doi: 10.1016/S0278-2391(99)90226-4]

\section{To cite this article:}

Hutchison C, Morrison R. Oral and Maxillofacial Trauma and the Use of Telemedicine in the Grampian Region of Scotland: a Retrospective Study.

J Oral Maxillofac Res 2012;3(3):e2

URL: http://www.ejomr.org/JOMR/archives/2012/3/e2/v3n3e2ht.pdf

doi: $10.5037 /$ jomr.2012.3302

Copyright (C) Hutchison C, Morrison R. Accepted for publication in the JOURNAL OF ORAL \& MAXILLOFACIAL RESEARCH (http://www.ejomr.org), 26 September 2012.

This is an open-access article, first published in the JOURNAL OF ORAL \& MAXILLOFACIAL RESEARCH, distributed under the terms of the Creative Commons Attribution-Noncommercial-No Derivative Works 3.0 Unported License, which permits unrestricted non-commercial use, distribution, and reproduction in any medium, provided the original work and is properly cited. The copyright, license information and link to the original publication on (http://www.ejomr.org) must be included. 